\title{
PENGARUH ON THE JOB TRAINING TERHADAP KUALITAS HUMAN CAPITAL SERTA IMPLIKASINYA PADA PENDAPATAN KARYAWAN
}

(Studi Persepsi Di PT Pindad Persero Bandung)

\author{
Lina Marlina ${ }^{1}$, Eeng Ahman² \\ Mahasiswa Magister Manajemen Bisnis \\ Sekolah Pasca Sarjana Universitas Pendidikan Indonesia
}

\begin{abstract}
Abstrak
Human capital sebagai penggerak suatu perusahaan selayaknya mendapat perhatian dari manajemen supaya selalu dinamis menghadapi tantangan bisnis yang ketat. Penurunan kualitas human capital di PT Pindad Persero Bandung dalam waktu tiga tahun terakhir menjadi perhatian peneliti untuk mencari tahu penyebab serta mendapatkan solusinya. Terkait permasalahan tersebut, pengembangan human capital yang berkaitan dengan on the job training dijadikan variabel yang menyajikan alternatif solusi. Penelitian ini bertujuan untuk menganalisis efektivitas on the job training, human capital dan pendapatan karyawan dengan dikontrol oleh variabel jenis kelamin, pendidikan dan masa kerja. Pengaruh on the job training terhadap human capital; pengaruh on the job training terhadap pendapatan; dan pengaruh human capital terhadap pendapatan karyawan. Metode penelitian ini menggunakan deskriptif dan eksplantori survei dengan menggunakan teknik proportionate random sampling terhadap 323 karyawan PT Pindad Persero yang terdistribusi secara proporsional. Instrumen penelitian menggunakan angket. Teknik analisis data menggunakan analisis jalur dan diolah dengan bantuan SPSS.22.00. Berdasarkan hasil penelitian, dapat disimpulkan bahwa on the job training, human capital dan pendapatan karyawan dengan dikontrol oleh variabel jenis kelamin, pendidikan dan lama kerja sudah dilakukan dengan efektif. On the job training berpengaruh positif signifikan terhadap human capital; on the job training berpengaruh positif signifikan terhadap pendapatan; dan human capital berpengaruh positif signifikan terhadap pendapatan karyawan PT Pindad Persero.
\end{abstract}

Kata Kunci: On The Job Training, Human capital, Pendapatan Karyawan, Jenis Kelamin, Pendidikan, Masa Kerja

\section{PENDAHULUAN}

Manajemen Sumber Daya Manusia (SDM) mengkaji dan memposisikan manusia sebagai suatu bentuk kapital atau dikenal dengan istilah modal manusia (human capital) seperti layaknya bentukbentuk kapital yang lain. Seperti yang dikemukakan oleh Yuniarsih (2008:17) “Manusia diposisikan sebagai bentuk kapital (human capital) seperti bentuk-bentuk kapital lainnya (seperti teknologi, mesin, tanah, uang, $\mathrm{dsb}$ ) yang sangat menentukan terhadap pertumbuhan produktivitas organisasi". Sehingga sumber daya manusia menjadi faktor produksi yang penting seperti faktor-faktor produksi lainnya. Bahkan sumber daya manusia memiliki keunggulan dibandingkan dengan faktor-faktor produksi lain.

Pentingnya hal tersebut sesuai dengan pendapat dari Mathis \& Jackson (2006:76) menyebutkan bahwa keunggulan SDM dibandingkan faktor produksi lainnya dalam strategi persaingan suatu perusahaan seperti: kemampuan inovasi dan entrepreneurship, kualitas yang unik, keahliaan yang khusus, pelayanan yang berbeda dan kemampuan produktivitas yang dapat dikembangkan sesuai kebutuhan.

Peranan sumber daya manusia, sama dan bahkan lebih baik dari faktor modal lain. Dengan lebih baik dan berkembangnya peranan tersebut, maka menggeserkan pula konsep human resources management kepada human capital management. Menurut Kearns 2005 (dalam Goal, 2014: 703) konsep human capital management berbeda dengan human resource management, jika human resource management berpendapat bahwa manusia dianggap signifikan sebagai biaya dan harus dikelola yang merugikan perusahaan, human capital mengganggap manusia sebagai asset intangible bukan merupakan overhead dan mampu menciptakan nilai. Manusia memiliki kelebihan kemampuan yang jika digunakan 
dan disebarkan akan semakin bertambah baik bagi individu itu sendiri atau untuk organisasi.

Konsep human capital sebenarnya sudah ada sejak zaman klasik. Adam Smith 1776, Heinrich Von Thunen 1875 dan para teorisi klasik lainya sebelum abad ke-19 yang menekankan pentingnya investasi keterampilan manusia (Irianto, 2011:6). Schultz (1961:4) kemudian memperlihatkan bahwa pembangunan sektor pendidikan dengan sumber daya manusia sebagai fokus dan intinya telah memberikan kontribusi langsung terhadap pertumbuhan ekonomi suatu negara, melalui peningkatan keterampilan dan kemampuan produksi dari tenaga kerja.

Investasi human capital dapat dilakukan dengan pendidikan, pelatihan, informasi, kesehatan, dan moral (Becker, 1993:60). Pendidikan dan pelatihan merupakan investasi yang paling umum dilakukan untuk meningkatkan pengetahuan dan keterampilan serta sikap dari seorang manusia. Semakin tinggi pendidikanya biasanya seseorang akan semakin terbuka pada pengalaman baru, semakin kuat cakrawala berfikirnya untuk meningkatkan kemampuan. Dalam dunia kerja pendidikan dilakukan dengan on the job training yakni pelatihan dengan instruksi pekerjaan. Pelatihan dengan cara on the job training tidak memerlukan terlalu banyak biaya karena dilakukan dalam aktivitas kerja.

Pada dunia nyata dalam pekerjaan terkadang pengetahuan yang di terima di sekolah belum begitu cocok dan pas pada pekerjaan yang dilakukan. Apalagi untuk fress graduate yang belum berpengalaman di dunia kerja. Bimbingan dan latihan dari senior atau supervisor benar-benar dibutuhkan. Supaya lebih efektif dan tepat guna maka perusahaan biasanya melaksanakan sebuah pelatihan on the job training (pelatihan dengan intruksi pekerjaan) sehingga pekerja pemula terampil menerapkan pengetahuan yang didapatkan dibangku sekolah dengan tuntutan pekerjaan yang sebenarnya.

Pelatihan dengan intruksi pekerjaan (on the job training) yang dilakukan akan menimbulkan peningkatan produktivitas tenaga kerja yang dimiliki perusahaan. Kecepatan yang dihasilkan dari produktivitas akan dapat menurunkan biaya produksi, sehingga kalkulasi perusahaan dapat menetapkan harga jual lebih rendah. Konsumen dapat membeli dengan harga murah, maka terjadilah peningkatan permintaan. Perusahaan memperoleh keuntungan dari repeat order yang terjadi, akhirnya akan memberikan upah kerja yang lebih baik lagi pada karyawanya.

Pendapatan dapat meningkat seiring pengingkatan kualitas human capital. Dengan menginvestasikan dirinya pada pelatihan diharapkan seseorang akan mampu meningkatkan keterampilan dalam bekerja sehingga pendapatan naik dan mendapat kesejahteraan hidup. Investasi dalam pelatihan akan menjadikan nilai tambah tersendiri bagi seseorang di masa yang akan datang, dengan mengorbankan waktu dan biaya saat ini seseorang tersebut dapat menikmati pendapatan yang lebih besar di kemudian hari. Nilai ekonomisnya terus berkembang melalui proses penambahan nilai seperti peningkatan wawasan, keterampilan, sikap, perilaku, dan keahlian.

Kenyataanya, selama ini pengukuran keberhasilan perusahaan lebih banyak dinilai dari laporan keuangan. Padahal keuangan bisa meningkat karena ada kekuatan dari perilaku karyawan yang berkualitas sehingga menghasilkan profit dan benefit yang tinggi. Dasar pemikiran tentang pentingnya meningkatkan kualitas human capital bahwasanya human capital merupakan ruh sebuah perusahaan. Sebuah komunitas bisnis atau perusahaan akan menjadi lambat, tidak berarti dan tergilas zaman, jika kualitas manusia di dalamnya sakit (tidak berkemampuan). Akhirnya menjadi buih yang banyak dan tidak diperhitungkan dalam cepatnya laju ekonomi.

Human capital yang berkualitas merupakan human capital yang mampu menyeimbangkan Psycologis, Intelektual, Emosional, Spiritualnya (Petterson \& Spiker, 2005:152). Keseimbangan yang dimiliki human capital dalam perusahaan akan membentuk pribadi karyawan yang unik. Keunikan tersebut dapat menjadikan perusahaan atau organisasi berbeda dengan perusahaan atau organisasi lainya. Keunikan yang dibawa setiap human capital itulah yang membedakanya. Karena, pentingnya peran human capital yang begitu besar dalam perusahaan, maka, 
manajemen perusahaan harus lebih proaktif menjadikan karyawanya sebagai human capital berkualitas. Perhatian dan pengembangan secara terus menerus harus dilakukan untuk mendapatkan human capital yang berkualitas tersebut supaya mampu menghadapi kedinamisan lingkungan bisnis. Terangkatnya penelitian tentang human capital ini diharapkan dapat sedikit mengisi kekosongan penelitian terkait topik tersebut. Penelitain human capital yang berkualitas diharapkan mampu memberikan performa tinggi untuk meningkatkan produktivitas dan pendapatan.

\section{KERANGKA PENELITIAN \& HIPOTESIS}

Garnd theory yang digunakan dalam penelitian ini adalah human resource management (HRM) yang bergeser dan berkembang perananya menjadi human capital management (HCM) dimana HRM menganggap manusia sebagai biaya sedangkan $\mathrm{HCM}$ memposisikan manusia sebagai asset yang akan memberikan nilai tambah pada perusahaan sehingga harus dikembangkan potensinya. Pada penelitian ini teori human capital yang diambil dari pemenang nobel yang melahirkan teori human capital yaitu Garry S Becker 1964.

Middle theory yang dimunculkan dari grand theory adalah organisasi pembelajar (learning organization) yang di dalamnya terdapat individu pembelajar yang meningkatkan kemampuan sehingga menghasilkan kinerja (performance). Kinerja atau performance tersebut akan menghasilkan standar tinggi jika dikelola dengan mengacu pada performance management. Kinerja dihasilkan dari perilaku seseorang saat bekerja dan berkaitan erat dengan karakteristik individu serta cara bekerjanya.

Teori penelitian ini merupakan teori human capital dari Becker mengungkapkan bahwa investasi human capital salah satunya dapat dilakukan dengan pelatihan (on the job training) serta investasi human capital akan berpengaruh pada pendapatan seseorang.
Untuk lebih jelasnya kerangka pemikiran digambarkan sebagai berikut:

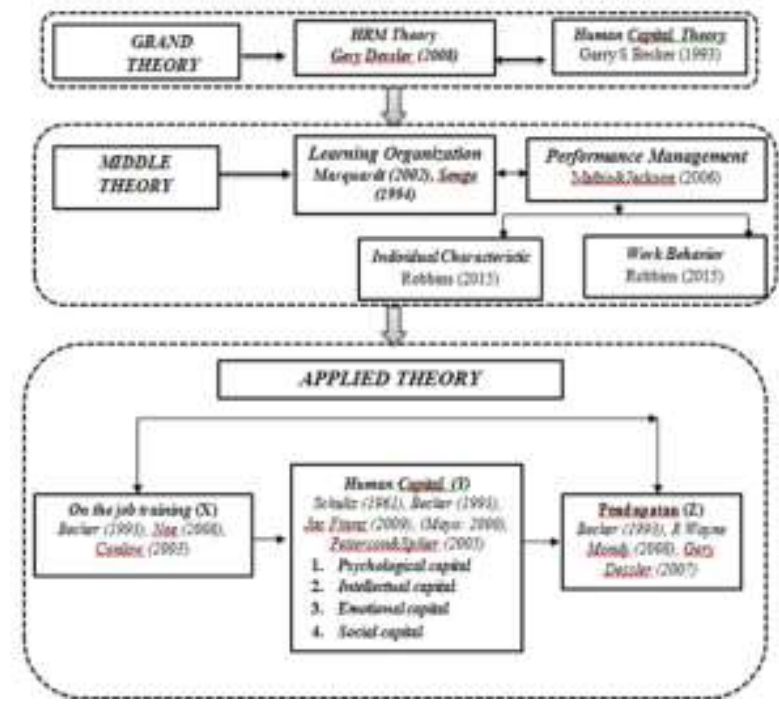

Gambar 3.1 Kerangka Pemikiran Penelitian

Dirumuskan paradigma keterkaitan variabel yang diteliti sebagai berikut :

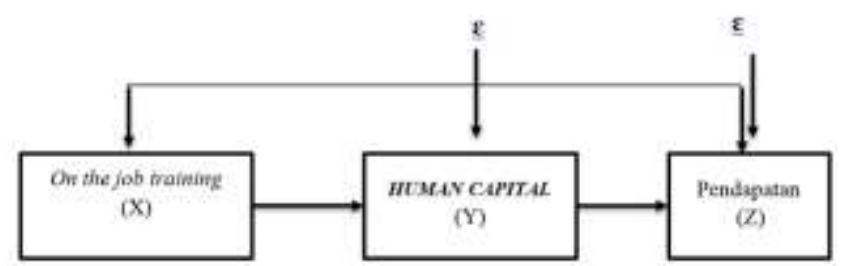

Gambar 3.2 Paradigma penelitian

A.

B. Hipotesis Penelitian

Secara konseptual dapat dirumuskan hipotesis penelitian sebagai berikut:

Hipotesis 1:

Terdapat pengaruh positif signifikan antara efektivitas on the job training terhadap tingkat kualitas human capital PT Pindad Persero

Hipotesis 2:

Terdapat pengaruh positif signifikan antara efektivitas on the job training terhadap tingkat pendapatan karyawan PT Pindad Persero

Hipotesis 3:

Terdapat pengaruh positif signifikan kualitas human capital terhadap tingkat pendapatan karyawan PT Pindad Persero.

\section{METODE PENELITIAN}


Penelitian menggunakan deskriptif survey dan explantory survey dilakukan melalui kegiatan pengumpulan informasi dari sebagian populasi secara langsung di tempat kejadian melalui alat kuisioner dengan tujuan untuuk mengetahui pendapat dari sebagian populasi yang diteliti terhadap permasalahan penelitian. Metode pengembangan yang digunakan adalah Cross Sectional seringkali disebut penelitian sekali bidik (one snap Shot).

Populasi penelitian yaitu karyawan PT Pindad (Persero) di Bandung yang telah melakukan pelatihan di learning center 2013 sebanyak 1655 orang. Teknik pengambilan sampel secara Probability Sampling dengan menggunakan teknik proportionate random sampling, selanjutnya sampel dipilih secara random pada sub populasi. Parameter yang diestimasikan sebanyak 323 orang dengan menggunakan rumus Slovin. Teknik analisis data menggunakan path analysis

\section{HASIL DAN PEMBAHASAN}

Berdasarkan matrik klasifikasi koefisien korelasi korelasi, bahwa on the job training terhadap human capital memiliki nilai 0,632 dikategorikan memiliki hubungan kuat.Berdasarkan hasil pengujian $\mathrm{F}$ dan Sig (Anova) terlihat bahwa $F_{\text {hitung }} 213,335$.

Sementara itu $F_{\text {tabel }} 3,952$ sehingga $F_{\text {hitung }}$ lebih besar

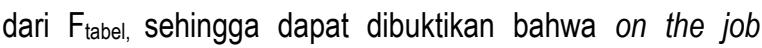

\section{KESIMPULAN}

Hasil penelitian sesuai dengan teori yang digunakan bahwa efektifitas on the job training mempengaruhi kualitas human capital. Kualitas human capital yang tinggi dapat meningkatkan produktivitas dan akhirnya berpengaruh pada persepsi peningkatan pendapatan karyawan. Kesimpulan umum tersebut menghasilkan bebrapa sub kesimpulan-kesimpulan sebagai berikut:

a. Deskripsi efektivitas on the job training, tingkat kualitas human capital dan tingkat pendapatan karyawan di PT Pindad (Persero) berdasarkan kontrol variabel training berpegaruh pada kualitas human capital. Selain itu terlihat juga bahwa nilai sig sebesar 0,000 yang berarti kurang dari 0,05 yang artinya on the job training berpegaruh secara positif dan signifikan pada kualitas human capital.

Tabel 4.1

Rangkuman Hasil Koefisien Jalur Sub Struktur 1

\begin{tabular}{cccccc}
$\begin{array}{c}\text { Pengaruh } \\
\text { antar } \\
\text { variabel }\end{array}$ & $\begin{array}{c}\text { Koefisien } \\
\text { Jalur }\end{array}$ & $t_{\text {hitung }}$ & $\mathbf{t}_{\text {tabel }}$ & Sig. & $\begin{array}{c}\text { Hasil } \\
\text { Pengujian }\end{array}$ \\
\hline $\begin{array}{c}\text { X terhadap } \\
\mathbf{Y}\end{array}$ & 0,632 & 14,606 & 1.98 & 0,000 & $\mathrm{H}_{\mathrm{o}}$ ditolak \\
\hline
\end{tabular}

Sumber: Hasil Pengolahan data 2015 dengan SPSS 22.00

Berdasarkan pengolahan data yang disajikan pada tabel 4.1 rangkuman hasil koefisien Jalur Sub Struktur 1 di atas, diketahui signifikansi untuk on the job training terhadap human capital adalah 0,000, sehingga dapat disimpulkan bahwa Ho ditolak. Pengujian hipotesis juga dapat dilihat dengan membandingkan harga nilai thitung dan harga ttabel untuk alfa 0,05 maka nilai ttabel adalah 1.98. thitung lebih besar dari ttabel maka Ho ditolak. Jadi pengujian signifikasi baik nilai signifikansi maupun uji-t samasama menghasilkan penolakan terhadap Ho. Berdasarkan hal tersebut dapat disimpulkan bahwa on the job training berpengaruh pada kualitas human capital.

Berdasarkan deskripsi jenis kelamin bahwa efektifitas on the job training mempengaruhi kualitas human capital dan pendapatan karyawan laki-laki dibandingkan perempuan. Berdasarkan pendidikan bahwa efektifitas on the job training mempengaruhi kualitas human capital dan pendapatan lulusan diploma. Berdasarkan masa kerja efektivitas on the job training di PT Pindad Persero sangat efektif dilakukan oleh karyawan baru 0-3 tahun dan keefektifan rendah dilakukan oleh karyawan lama yang bekerja di atas 10 tahun. Kualitas human capital yang tinggi berada pada karyawan senior yang bekerja 5-10 dan rendah pada karyawan baru 3-5 tahun. Tingkat pendapatan efektif tinggi didapatkan oleh karyawan baru 0-3 tahun dan rendah bagi karyawan yang bekerja 5-10 tahun. 
b. Terdapat pengaruh positif signifikan on the job training terhadap human capital PT Pindad Persero.

Hasil penelitian menginformasikan bahwa on the job training berkontribusi positif signifikan pada kualitas human capital karyawan PT Pindad Persero. Artinya semakin efektif on the job training dilaksanakan maka tingkat kualitas human capital semakin tinggi.

c. Terdapat pengaruh positif signifikan on the job training terhadap pendapatan (earning) karyawan PT Pindad Persero.

Hasil penelitian ini menginformasikan bahwa on the job training berkontribusi positif signifikan pada pendapatan karyawan PT Pindad Persero. Artinya semakin efektif on the job training dilaksanakan maka tingkat pendapatan karyawan semakin tinggi, dengan asumsi meningkatnya kualitas human capital sebanding dengan meningkatnya produktivitas.

d. Terdapat pengaruh positif signifikan human capital terhadap pendapatan (earning) karyawan PT Pindad Persero.

Hasil penelitian menginformasikan bahwa kualitas human capital berkontribusi positif signifikan pada pendapatan karyawan PT Pindad Persero. Artinya semakin tinggi kualitas human capital maka tingkat pendapatan karyawan semakin meningkat

\section{REKOMENDASI}

\section{a. Bagi Perusahaan}

Dari kesimpulan di atas, untuk mencapai maksud dan tujuan peningkatan kesejahteraan karyawan melalui peningkatan pendapatan dan kualitas diri, maka disarankan sebagai berikut:

1) Perusahaan sebaiknya melanjutkan pelatihan on the job untuk laki-laki dan memperhatikan metode lain untuk karyawan perempuan supaya lebih effektif. Selain itu perlu diperhatikan dari segi evaluasi waktu, proporsi peserta dan menentukan prioritas pelatihan dari yang paling urgent.

2) Perusahaan sebaiknya merekrut karyawan Iulusan diploma untuk melakukan hal-hal teknis, merekrut lulusan S1 untuk pekerjaan yang berkaitan konsep serta merekrut S2 untuk pekerjaan yang berkaitan kebijakan demi perkembangan perusahaan di masa mendatang.

3) Perusahaan sebaiknya memperhatikan kualitas human capital untuk Iulusan SMA dalam memaknai pekerjaan dan lulusan S2 tentang manajemen stress

4) Perusahaan sebaiknya melanjutkan pelatihan on the job untuk karyawan yang bekerja 0-10 tahun, dan mencari metode lain untuk meningkatkan kualitas human capital karyawan yang bekerja di atas 10 tahun.

5) Perusahaan sebaiknya lebih memperhatikan tingkat pendapatan karyawan berdasarkan level pendidikan..

6) Perusahaan sebaiknya lebih memperhatikan tingkat pendapatan karyawan berdasarkan masa kerja..

7) Kualitas human capital tentang sosial capital yang masih rendah, sebaiknya perusahaan menyediakan kendaraan yang selalu mobile di area perusahaan supaya akses lebih cepat dan sosialisasi lebih mudah.

b. Peneliti

Penelitian ini terbatas dengan meneliti kualitas human capital dari sisi on the job training. Peneliti selanjutnya diharapkan menggunakan faktor lain selain on the job training untuk meningkatkan kualitas human capital. Banyak faktor lain untuk meningkatkan human capital seperti schooling, kesehatan, migrasi dan lainya.

\section{DAFTAR PUSTAKA}

Beacker, S, Gerry. 1993. Human Capital. A Theoritical and Ampirical Analisis with Special Referene to Education 3th Edition. London: The University of Cicago Press.

Conlow, Rick. 2003. Menjadi Supervisor HebatKeterampilan. Pokok Bagi Supervisor Baru diterjemahkan oleh Kumala Insiwi Suryo. Jakarta: PPM. 
Dessler, Gary. 2007. Manajemen Sumber Daya Manusia. Edisi Kesepuluh. Jilid 2. Jakarta : PT. Indeks.

Fattah. Nanang, 2009. Ekonomi dan Pembiayaan Pendidikan. Edisi kelima. Bandung: Remaja Rosda Karya.

Goal, Jimmy, L. 2014. A to Z Human Capital Manajemen Sumber Daya Manusia. Jakarta : Grasindo.

Håkan Regnér. 2002. The effects of on-the-job training on wages in Sweden. International Journal of Manpower.

Irianto, Agus. 2011. Pendidikan Sebagai Investasi Dalam Pembangunan Suatu Negara. Kencana Jakarta : Predana Media Grup.

Ivancevich, John M. 2007. Human Resource Management Tenth Edition. Singapore : McGraw Hill Internasional.Jac Fitenz (2009:xiii)

Jonathan R. Veum. 1995. Training, Wages, and the Human Capital Model U.S. Department Of Labor. Bureau of Labor Statistics US Massachusetts Mathis, Robert L. dan John H. Jakson. 2006. Human Resource Management, South-Western: Thomson Learning.

Mayo, A. 2000. The Role of Employee Development in The Growth of Intellectual Capital dalam Personal Review, Vol. 29, No. 4.

Mirfani, AM. 2010. Strategi Dasar Pembangunan Sistem Pendidikan Nasional Dengan Reposisi Investasi SDM Indonesia Abad 21. FIP. IKIP Bandung.

Mondy, R. Wayne. 2008. Manajemen Sumber Daya Manusia. Edisi Kesepuluh. Jakarta: Erlangga.

Noe, Raymond.A. 2005. Employee Training and Development. New York : Mc Graw-Hill.

Panggabean, Mutiara. S, 2004. Manajemen Sumber Daya Manusia. Bogor: Ghalia Indonesia.

Richard Blundell, at al. 1999. Human Capital Investment: The Returns from Education and Training to the Individual. the Firmand the Economy Fiscal Studies.

Rita K.A, Marta Faria. 2014. The wage returns to on-the-job training: evidence from matched employer-employee. IZA Journal of Labor \& Development.

Schultz, Theodore, W. 1961. Investment in Human Capital. The American Economic. Review, Vol. 51, No. 1 (Mar., 1961), pp.1-7.

Sofyandi, Herman. 2008. Manajemen Sumber Daya Manusia, edisi pertama, Yogyakarta: Graha IImu.
Stefan Tupamahu \& Budi W.S. 2005. Pengukuran Return On Training Investement (ROTI). Artikel Majalah Usahawan LMFEUI.

Sultana, Afshan. et. Al. 2012 Impact Of Training On Employee Performance: A Study of Telecommunication Sector In Pakistan. Interdisciplinary Journal Of Contemporary Research In Business Copy Right (? 2012 Institute Of Interdisciplinary Business Research 646 October 2012 Vol 4, NO 6.

Supratno, J. 2007. Statistik Teori dan Aplikasi. Jakarta: Erlanggga.

Yuniarsih, Tjutju dan Swatno. 2008. Manajemen Sumber Daya Manusia. Bandung: Alfabeta. 